\title{
Direct molecular versus culture-based assessment of Gram-positive cocci in biopsies of patients with major abscesses and diabetic foot infections
}

\author{
M. H. T. Stappers ${ }^{1,2,3}$ - F. Hagen ${ }^{2}$ • P. Reimnitz ${ }^{4}$ J. W. Mouton ${ }^{5,6}$ - J. F. Meis ${ }^{2,5,6}$ • \\ I. C. Gyssens ${ }^{1,2,3}$
}

Received: 20 May 2015 / Accepted: 11 June 2015 / Published online: 5 July 2015

(C) The Author(s) 2015. This article is published with open access at Springerlink.com

\begin{abstract}
Major abscesses and diabetic foot infections (DFIs) are predominant subtypes of complicated skin and skin structure infections (cSSSIs), and are mainly caused by Staphylococcus aureus and $\beta$-hemolytic streptococci. This study evaluates the potential benefit of direct pathogenspecific real-time polymerase chain reaction (PCR) assays in the identification of causative organisms of cSSSIs. Onehundred and fifty major abscess and 128 DFI biopsy samples were collected and microbial DNA was extracted by using the Universal Microbe Detection kit for tissue samples. Pathogenspecific PCRs were developed for $S$. aureus and its virulence factor Panton-Valentine leukocidin (PVL), Streptococcus pyogenes, $S$. agalactiae, $S$. dysgalactiae, and the $S$. anginosus group. Identification by pathogen-specific PCRs was compared to routine culture and both methods were considered as the gold standard for determination of the sensitivity and specificity of each assay. Direct real-time PCR assays of biopsy samples resulted in a $34 \%$ higher detection of $S$. aureus, $37 \%$ higher detection of $S$. pyogenes, $18 \%$ higher detection of $S$. agalactiae, $4 \%$ higher detection of
\end{abstract}

I. C. Gyssens

inge.gyssens@radboudumc.nl

1 Department of Internal Medicine, Radboud University Medical Center, P.O. Box 9101, 6500 HB Nijmegen, The Netherlands

2 Department of Medical Microbiology and Infectious Diseases, Canisius-Wilhelmina Hospital, Nijmegen, The Netherlands

3 Hasselt University, Hasselt, Belgium

4 Bayer Healthcare Pharmaceuticals, Wuppertal, Germany

5 Department of Medical Microbiology, Radboud University Medical Center, Nijmegen, The Netherlands

6 Department of Medical Microbiology and Infectious Diseases, Erasmus MC, Rotterdam, The Netherlands
S. dysgalactiae subspecies equisimilis, and $7 \%$ higher detection of the $S$. anginosus group, compared to routine bacterial culture. The presence of PVL was mainly confined to $S$. aureus isolated from major abscess but not DFI biopsy samples. In conclusion, our pathogen-specific real-time PCR assays had a higher yield than culture methods and could be an additional method for the detection of relevant causative pathogens in biopsies.

\section{Introduction}

Major abscesses and diabetic foot infections (DFIs) are the predominant subtypes of a spectrum of infections termed complicated skin and skin structure infections (cSSSIs). The Food and Drug Administration (FDA) defined cSSSIs as infections of the deeper soft tissues, involving surgical intervention or a significant underlying disease state that complicates the response to treatment. Superficial infections located in an anatomical site in which the chance of involvement of anaerobic or Gram-negative pathogens is high should also be considered as cSSSIs [1, 2]. cSSSIs are associated with significant morbidity and mortality, as well as prolonged and expensive hospitalizations [3]. The management of cSSSIs involves surgical debridement of the infection, combined with antibiotic therapy [4].

Gram-positive cocci, in particular Staphylococcus aureus and $\beta$-hemolytic streptococci, are the leading causative organisms of cSSSIs $[2,4]$. In a recent multicenter randomized clinical trial, $65 \%$ of the cultured isolates consisted of Gram-positive cocci (S. aureus $33 \%$ and $\beta$-hemolytic streptococci $15 \%)$, whereas Gram-negative bacilli $(28 \%)$ and anaerobes (7\%) were found to a lesser extent [5], but geographical differences exist in the type and amount of species isolated [6]. Correct and rapid identification of pathogens is 
crucial for clinical decision-making and optimal antibiotic therapy. Up to now, routine bacteriological assessment of biopsies from cSSSIs relies upon culture, which, in order to be successful, requires viable pathogens in tissue and the use of suitable culture conditions for growth. Difficult to culture pathogens, those present in low numbers or that died before/ during sampling of the infected tissue make detection by culture complicated and time-consuming. This may result in low sensitivity and underestimated bacterial prevalence. Several molecular assays, such as pathogen-specific, broad-range, and multiplex polymerase chain reaction (PCR) assays, either directly on clinical samples or cultured isolates, have been developed in recent years to improve bacteriological detection $[7,8]$. This study evaluates the potential benefit of direct, pathogen-specific real-time PCR assays on clinical samples in the identification of the causative organisms of cSSSIs.

Biopsy samples of 150 major abscesses and 128 DFIs were collected during a multicenter clinical trial involving patients with cSSSIs [5]. Detection of the pathogens $S$. aureus and Streptococcus species by real-time PCR directly on DNA isolated from these clinical cSSSI samples was compared to routine cultures.

\section{Materials and methods}

\section{Definitions}

cSSSIs were characterized as infections of bacterial origin that required hospitalization, initial parenteral therapy for $\geq 48 \mathrm{~h}$, and which met at least one of the following criteria: deep soft tissue involvement; significant surgical intervention, including drainage and/or debridement; and association with an underlying comorbid condition. Major abscesses were defined as collections of pus associated with extensive cellulitis, requiring surgical intervention followed by antibiotic therapy. DFIs were characterized as infections occurring below the ankle in patients with confirmed diabetes [5].

\section{Collection of major abscess and DFI biopsy samples}

From a population of 813 cSSSI patients included in a large randomized, multicenter clinical trial [5], performed from September 2006 to June 2008, 389 patients gave informed consent to participate in this substudy. Of these, the first visit, prestudy treatment biopsy samples were selected, resulting in the inclusion of 150 major abscess and 128 DFI samples from 225 cSSSI patients. Samples were collected via biopsy of tissue or bone, curettage of the wound, or aspiration of purulent discharge. After collection, samples were directly stored in preservation medium (BBL Port-A-Cul Transport vial, Becton Dickinson, Franklin Lakes, NJ, USA) and transported within $72 \mathrm{~h}$ to the central laboratory (Eurofins Medinet SAS,
Plaisir, France) [5]. On arrival, samples were split into two, one part for immediate culture and identification by using standard clinical laboratory procedures, and the other part was stored at $-80{ }^{\circ} \mathrm{C}$ for subsequent DNA isolation and PCR analysis.

\section{Bacterial DNA extraction from biopsy samples}

Pathogen DNA was manually extracted by using the MolYsis Universal Microbial Detection kit for tissue samples (Molzym, Bremen, Germany), following the manufacturer's instructions. Briefly, selective lysis of human cells is performed, followed by degradation of human DNA. After washing the pellet, a second round of DNA extraction is performed to release DNA from bacterial and fungal cells. This approach enables an increased sensitivity and specificity for pathogen DNA, since interfering non-target human DNA is no longer present [9]. Pathogen DNA extraction was carried out in a laminar flow cabinet to prevent contamination. Prior to further handling, the DNA samples were stored at $-20^{\circ} \mathrm{C}$.

\section{Real-time PCR primer and probe design}

To detect $S$. agalactiae, in both subspecies of $S$. dysgalactiae and $S$. pyogenes, the recA gene was chosen as the target, based on the results from previous studies [10, 11]. Partial recA sequences of clinically relevant Streptococcus species were extracted from GenBank (accession numbers EU156792EU156872), an alignment was generated in MEGA v6 [12], and primer and probe sets were developed to make sure that there was no overlap with other Streptococcus species. The specificity of the primers and probes were in silico tested by a BLAST search in GenBank.

A previously described multiplex real-time PCR assay was used to detect the $S$. aureus-specific fragment Sa442 and the Panton-Valentine leukocidin (PVL) gene [13].

The duplex real-time PCRs were performed in reaction volumes of $20 \mu \mathrm{L}$ consisting of $10 \mu \mathrm{L} 2 \times$ LC480 Probe Master Mix (Roche Diagnostics), $0.1 \mu \mathrm{L}$ of each primer and $0.04 \mu \mathrm{L}$ of both probes $(100 \mathrm{pmol} / \mu \mathrm{L}$; Eurogentec, Brussels, Belgium), $1.72 \mu \mathrm{L} \mathrm{ddH}_{2} \mathrm{O}$, and $8 \mu \mathrm{L}$ sample DNA. The PCRs were performed with the following settings: initial denaturation step for $10 \mathrm{~min}$ at $95{ }^{\circ} \mathrm{C}, 50$ cycles of $1 \mathrm{~s}$ at $95{ }^{\circ} \mathrm{C}$, $12 \mathrm{~s}$ at $60^{\circ} \mathrm{C}$, followed by measuring the fluorescence signal, and a cooldown step for $30 \mathrm{~s}$ at $40{ }^{\circ} \mathrm{C}$.

For detection of members of the $S$. anginosus group (S. anginosus, S. constellatus, and S. intermedius, also termed the $S$. milleri group), a set of primers was developed based on an alignment made in MEGA v6 of the $r e c N$ sequences EU917226-EU917315 [12, 14]. The PCRs were performed in $10 \mu \mathrm{L}$ reaction volumes, containing $5 \mu \mathrm{L} 2 \times$ LC480 Probe Master Mix (Roche Diagnostics, Almere, the Netherlands), $0.5 \mu \mathrm{L}$ of each primer $(10 \mathrm{pmol} / \mu \mathrm{L}$; Eurogentec $), 0.5 \mu \mathrm{L}$ 
SYTO82 (40 $\mu \mathrm{M}$; Molecular Probes, Eugene, OR, USA), $2.5 \mu \mathrm{L} \mathrm{ddH}_{2} \mathrm{O}$, and $1 \mu \mathrm{L}$ sample DNA. The following PCR program was used: initial denaturation for $10 \mathrm{~min}$ at $95{ }^{\circ} \mathrm{C}, 35$ cycles of $5 \mathrm{~s}$ at $95{ }^{\circ} \mathrm{C}, 5 \mathrm{~s}$ at $60{ }^{\circ} \mathrm{C}$, and $10 \mathrm{~s}$ at $72{ }^{\circ} \mathrm{C}$, followed by a melting curve analysis at $65{ }^{\circ} \mathrm{C}$ to $95{ }^{\circ} \mathrm{C}$. Fluorescence was measured after each extension step.

The primer and probe sequences of all assays are provided in Table 1.

\section{Real-time PCR assays and analysis}

The analytic specificity was tested by applying the newly developed Streptococcus assays on a set of 62 clinically relevant Streptococcus reference strains. The sensitivity of the Streptococcus assays was performed by applying two-step dilution series of the relevant type strains, starting with an input ranging from $0.01 \mathrm{ng}$ to $4.9 \mathrm{fg}$ per reaction. The equivalent of genomic copies per reaction was calculated based on the genome sizes for each of the Streptococcus species [15, $16]$.

Table 1 Primer and probe sequences

\begin{tabular}{|c|c|c|c|}
\hline Specificity & Forward primer & Probe & Reverse primer \\
\hline S. aureus* & $\begin{array}{l}\text { 5'-ACGA } \\
\text { CTARATAA } \\
\text { ACGCTCAT } \\
\text { TCG-3' }\end{array}$ & $\begin{array}{l}\text { 5'-HEX-TGAAAT } \\
\text { CTCATTACGT } \\
\text { TGCATCGGA- } \\
\text { BHQ1-3' }\end{array}$ & $\begin{array}{c}\text { 5'-GACGGC } \\
\text { TTTTACAT } \\
\text { ACAGAA } \\
\text { CACA-3' }\end{array}$ \\
\hline PVL* & $\begin{array}{c}\text { 5'-AAAAAG } \\
\text { GCTCAG } \\
\text { GAGATA } \\
\text { CAAGTG - } \\
\text { 3' }\end{array}$ & $\begin{array}{l}\text { 5'-Cy5-TGGCAG } \\
\text { AAATATGGAT } \\
\text { GTTACTCATG } \\
\text { C-BHQ2-3' }\end{array}$ & $\begin{array}{c}\text { 5'-TGCCAT } \\
\text { AGTGTG } \\
\text { TTGTTCTT } \\
\text { CTAGT-3' }\end{array}$ \\
\hline S. pyogenes & $\begin{array}{l}\text { 5'-TTGGAA } \\
\text { ACGATA } \\
\text { GCTAATAC } \\
\text { CG-3' }\end{array}$ & $\begin{array}{l}\text { 5'-HEX-CGCATG } \\
\text { TTAGTAATTT } \\
\text { AAAAGGGGCA } \\
\text {-BHQ1-3' }\end{array}$ & $\begin{array}{c}\text { 5'-CGCAGG } \\
\text { TCCATC } \\
\text { TCATAG } \\
\text { TG-3' }\end{array}$ \\
\hline S. agalactiae & & $\begin{array}{l}\text { 5'-FAM-TGTTAG } \\
\text { TTATTTAAAA } \\
\text { GGAGCAATTG } \\
\text { C-BHQ1-3' }\end{array}$ & \\
\hline $\begin{array}{c}\text { S.dysgalactiae } \\
\text { equisimilis }\end{array}$ & & $\begin{array}{l}\text { 5'-HEX-CCCATG } \\
\text { TTAAACATTT } \\
\text { AAAAGGTGCA } \\
\text {-BHQ1-3' }\end{array}$ & \\
\hline $\begin{array}{l}\text { S.dysgalactiae } \\
\text { dysgalacti- } \\
\text { ae }\end{array}$ & & $\begin{array}{l}\text { 5'-FAM-AATGGA } \\
\text { GGACCCATGT } \\
\text { CTTTCATTT- } \\
\text { BHQ1-3' }\end{array}$ & \\
\hline $\begin{array}{l}\text { S. anginosus } \\
\text { group }\end{array}$ & $\begin{array}{l}\text { 5'-TGGACA } \\
\text { GCATTTGG } \\
\text { TGGATA-3' }\end{array}$ & $\mathrm{n} / \mathrm{a}$ & $\begin{array}{l}\text { 5'-GCTTAC } \\
\text { GCAACT } \\
\text { GACGAT } \\
\text { ACTG-3' }\end{array}$ \\
\hline
\end{tabular}

*This assay was previously published by Hopman et al. [13]

\section{Statistical analysis}

McNemar's test was performed to study differences between real-time PCR and culture-based assessment of pathogenic presence, for major abscesses and DFIs separately. The results for major abscesses and DFIs were combined for the determination of the sensitivity, specificity, positive predictive value (PPV), and negative predictive value (NPV). Both culture and real-time PCR were considered as the gold standard.

\section{Results}

\section{Validation of species-specific Streptococcus real-time PCR} assays and analysis

The S. agalactiae real-time PCR assay was found to be positive for the included strains; however, atypical amplification curves were observed for two $S$. anginosus strains. The $S$. pyogenes assay, included in the duplex real-time PCR with $S$. agalactiae, was found to be exclusively positive for strains that belong to this species. The $S$. dysgalactiae duplex realtime PCR assay was positive for the included subspecies dysgalactiae and equisimilis. However, the assay for subspecies equisimilis showed an atypical amplification curve for one strain of $S$. constellatus and S. cristatus.

The lower limit of detection was found to be at the 9th dilution step for the targets $S$. agalactiae, both subspecies of S. dysgalactiae and S. pyogenes, equivalent of $\sim 39$ fg DNA per reaction, equal to $\sim 17$ genomic copies per reaction. For the intercalating dye-based assay for $S$. anginosus, S. constellatus and $S$. intermedius assay, the lower limit of detection was found to be at the 8 th dilution step, equal to $78 \mathrm{fg}$ or $\sim 37$ genomic copies per reaction.

\section{Real-time PCR versus culture-based assessment of $S$. aureus prevalence in major abscesses and DFIs}

The first visit biopsy samples of 150 major abscesses and 128 DFIs were collected, and the identification of $S$. aureus was performed by real-time PCR and culture. Of the 150 major abscess samples, $81 \%$ were positive for $S$. aureus by real-time PCR, whereas $44 \%$ were culture-positive for $S$. aureus. None of the culture-positive samples were real-time PCR-negative (Table 2). Of the 128 DFI samples, $88 \%$ were positive for S. aureus by real-time PCR, whereas $57 \%$ were culturepositive for $S$. aureus. One culture-positive sample was found to be real-time PCR-negative (Table 2). Subsequent real-time PCR determination of the cultured strain from the culturepositive, real-time PCR-negative biopsy sample confirmed the presence of $S$. aureus. Statistical analysis using McNemar's test showed a significant difference between S. aureus real-time PCR and culture-based assessment for 
Table 2 Real-time polymerase chain reaction (real-time PCR) versus culture-based assessment of Gram-positive coccal prevalence in major abscesses and diabetic foot infections

\begin{tabular}{lll} 
Major abscesses & & \\
\hline Real-time & Real-time & Total \\
PCR-positive & PCR-negative &
\end{tabular}

Diabetic foot infections

$\begin{array}{lll}\text { Real-time } & \text { Real-time } & \text { Total } \\ \text { PCR-positive } & \text { PCR-negative } & \end{array}$

S. aureus

Culture-positive

Culture-negative

66

55

0

Total

121

29

29

66

84

150

Culture-positive

Culture-negative

Total

72

41

113

14

15

55

128

S. pyogenes

Culture-positive

Culture-positive

1

Culture-negative

18

1

Culture-negative $\quad 104$

23

150

Total

19

109

127

S. agalactiae

Culture-positive

Culture-negative

3

8

142

Total

100

103

150

Culture-positive

Culture-negative

Total

18

21

39

79

89

S. dysgalactiae subspecies equisimilis

Culture-positive

Culture-negative 0

14

4

146

Culture-positive

Culture-negative

16

12

Total

28

1

99

17

150

S. anginosus group

Culture-positive

Culture-negative

Total

16

7

23

127

150

Culture-positive

6

Culture-negative

Total

13

19

108

7

121

121

109

128 major abscesses $(p<0.001)$ and DFIs $(p<0.001)$. The sensitivity, specificity, PPV, and NPV for the $S$. aureus real-time PCR and culture are shown in Table 3.

\section{Real-time PCR-based assessment of PVL versus $S$. aureus prevalence in major abscesses and DFIs}

The presence of $S$. aureus virulence factor PVL was determined by real-time PCR and correlated to $S$. aureus realtime PCR-positive biopsies. Of interest, the majority of S. aureus real-time PCR-positive major abscess samples were also PVL real-time PCR-positive (89 \%). In contrast, a minority of $S$. aureus real-time PCR-positive DFI samples were PVL real-time PCR-positive (14\%). In both groups of major abscesses and DFIs, two samples were PVL real-time PCRpositive but not $S$. aureus real-time PCR-positive (Table 4).

\section{Real-time PCR versus culture-based assessment of $S$. pyogenes prevalence in major abscesses and DFIs}

Of the 150 major abscess samples, $85 \%$ were positive for $S$. pyogenes by real-time PCR, whereas $15 \%$ were culture- positive for $S$. pyogenes. None of the culture-positive samples were real-time PCR-negative (Table 2). Of the 128 DFI samples, $15 \%$ were positive for $S$. pyogenes by real-time PCR, whereas $1 \%$ were culture-positive for $S$. pyogenes. The only culture-positive sample was also real-time PCR-positive (Table 2). Statistical analysis showed a significant difference between $S$. pyogenes real-time PCR and culture-based assessment for major abscesses $(\mathrm{p}<0.001)$ and DFIs $(p<0.001)$. The sensitivity, specificity, PPV, and NPV for the S. pyogenes realtime PCR and culture are shown in Table 3.

\section{Real-time PCR versus culture-based assessment of $S$. agalactiae prevalence in major abscesses and DFIs}

Of the 150 major abscess samples, $31 \%$ were positive for S. agalactiae by real-time PCR, whereas $5 \%$ were culturepositive for $S$. agalactiae. Three culture-positive samples were real-time PCR-negative (Table 2). Of the 128 DFI samples, $30 \%$ were positive for $S$. agalactiae by real-time PCR, whereas $22 \%$ were culture-positive for $S$. agalactiae. Ten culturepositive samples were real-time PCR-negative (Table 2). Subsequent real-time PCR determination of the cultured 
Table 3 Sensitivity, specificity, positive predictive value (PPV), and negative predictive value (NPV) of real-time polymerase chain reaction (real-time PCR) and culture-based assessment of Gram-positive coccal prevalence in major abscesses and diabetic foot infections

\begin{tabular}{|c|c|c|c|c|c|c|}
\hline Species & Reference & Assay & Sensitivity (\%) & Specificity (\%) & PPV (\%) & NPV (\%) \\
\hline \multirow[t]{2}{*}{ S. aureus } & Culture & Real-time PCR & 99 & 31 & 59 & 98 \\
\hline & Real-time PCR & Culture & 59 & 98 & 99 & 31 \\
\hline \multirow[t]{2}{*}{ S. pyogenes } & Culture & Real-time PCR & 100 & 86 & 16 & 100 \\
\hline & Real-time PCR & Culture & 16 & 100 & 100 & 86 \\
\hline \multirow[t]{2}{*}{ S. agalactiae } & Culture & Real-time PCR & 64 & 74 & 27 & 93 \\
\hline & Real-time PCR & Culture & 27 & 93 & 64 & 74 \\
\hline \multirow[t]{2}{*}{ S. dysgalactiae equisimilis } & Culture & Real-time PCR & 91 & 95 & 61 & 99 \\
\hline & Real-time PCR & Culture & 61 & 99 & 91 & 95 \\
\hline \multirow[t]{2}{*}{ S. anginosus group } & Culture & Real-time PCR & 73 & 90 & 46 & 97 \\
\hline & Real-time PCR & Culture & 46 & 97 & 73 & 90 \\
\hline
\end{tabular}

strains from the 13 culture-positive, real-time PCR-negative biopsy samples confirmed the presence of $S$. agalactiae of four strains. The other nine strains were negative for S. agalactiae real-time PCR. Statistical analysis showed a significant difference between $S$. agalactiae real-time PCR and culture-based assessment for major abscesses $(p<0.001)$ but not DFIs $(p>0.05)$. The sensitivity, specificity, PPV, and NPV for the S. agalactiae real-time PCR and culture are shown in Table 3.

\section{Real-time PCR versus culture-based assessment} of $S$. dysgalactiae prevalence in major abscesses and DFIs

Of the 150 major abscess samples, $2 \%$ were positive for S. dysgalactiae subspecies equisimilis by real-time PCR, whereas $3 \%$ were culture-positive for $S$. dysgalactiae subspecies equisimilis. One of the culture-positive samples was real-time PCR-negative (Table 2). Of the 128 DFI samples, $22 \%$ were positive for $S$. dysgalactiae subspecies equisimilis by real-time PCR, whereas $13 \%$ were culture-positive for S. dysgalactiae subspecies equisimilis. One DFI sample was found to be culturepositive but real-time PCR-negative (Table 2). Subsequent real-time PCR determination of the cultured strains from the two culture-positive, real-time PCR-negative biopsy samples confirmed the presence of $S$. dysgalactiae subspecies equisimilis of one strain. The other strain was negative for $S$. dysgalactiae subspecies equisimilis real-time PCR. Statistical analysis showed a significant difference between $S$. dysgalactiae subspecies equisimilis real-time PCR and culture-based assessment for DFIs $(p<0.01)$ but not major abscesses $(p>0.05)$. The sensitivity, specificity, PPV, and NPV for the $S$. dysgalactiae subspecies equisimilis real-time PCR and culture are shown in Table 3.

None of the 150 major abscess samples were real-time PCR or culture positive for $S$. dysgalactiae subspecies dysgalactiae. Of the 128 DFI samples, only one sample was positive for $S$. dysgalactiae subspecies dysgalactiae by realtime PCR but culture-negative, and, also, one sample was culture-positive for $S$. dysgalactiae subspecies dysgalactiae but real-time PCR-negative. Subsequent real-time PCR determination of the cultured strain from the culture-positive, realtime PCR-negative biopsy sample was negative for $S$. dysgalactiae subspecies dysgalactiae but positive for S. dysgalactiae subspecies equisimilis.

\section{Real-time PCR versus culture-based assessment of $S$. anginosus group prevalence in major abscesses and DFIs}

S. anginosus, $S$. constellatus, and S. intermedius together constitute the $S$. anginosus group. Of the 150 major abscess samples, $19 \%$ were positive for members of the $S$. anginosus

Table 4 Real-time polymerase chain reaction (real-time PCR)-based assessment of Panton-Valentine leukocidin (PVL) versus Staphylococcus aureus prevalence in major abscesses and diabetic foot infections

\begin{tabular}{|c|c|c|c|c|c|c|c|}
\hline & \multicolumn{3}{|l|}{ Major abscesses } & & \multicolumn{3}{|c|}{ Diabetic foot infections } \\
\hline & $\begin{array}{l}\text { S. aureus real-time } \\
\text { PCR-positive }\end{array}$ & $\begin{array}{l}\text { S. aureus real-time } \\
\text { PCR-negative }\end{array}$ & Total & & $\begin{array}{l}\text { S. aureus real-time } \\
\text { PCR-positive }\end{array}$ & $\begin{array}{l}\text { S. aureus real-time } \\
\text { PCR-negative }\end{array}$ & Total \\
\hline $\begin{array}{l}\text { PVL real-time } \\
\text { PCR-positive }\end{array}$ & 108 & 2 & 110 & $\begin{array}{l}\text { PVL real-time } \\
\text { PCR-positive }\end{array}$ & 16 & 2 & 18 \\
\hline $\begin{array}{l}\text { PVL real-time } \\
\text { PCR-negative }\end{array}$ & 13 & 27 & 40 & $\begin{array}{l}\text { PVL real-time } \\
\text { PCR-negative }\end{array}$ & 97 & 13 & 110 \\
\hline Total & 121 & 29 & 150 & Total & 113 & 15 & 128 \\
\hline
\end{tabular}


group by real-time PCR, whereas $15 \%$ were culture-positive for members of the $S$. anginosus group. Seven culture-positive samples were real-time PCR-negative (Table 2). Of the 128 DFI samples, $15 \%$ were positive for members of the S. anginosus group by real-time PCR, whereas $6 \%$ were culture-positive for members of the $S$. anginosus group. One culture-positive sample was real-time PCR-negative (Table 2). Subsequent real-time PCR determination of the cultured strains from the eight culture-positive, real-time PCR-negative biopsy samples confirmed identification of the $S$. anginosus group of six strains. Of the two other strains, one was negative for $S$. anginosus group real-time PCR and the other strain was not viable. Statistical analysis showed a significant difference between $S$. anginosus group real-time PCR and culture-based assessment for DFIs $(p<0.01)$ but not major abscesses $(p>0.05)$. The sensitivity, specificity, PPV, and NPV for the $S$. anginosus group real-time PCR and culture are shown in Table 3.

\section{Discussion}

This study is the first to demonstrate that the use of direct realtime PCR versus culture-based assessment for the determination of pathogens in clinical biopsy samples of patients with major abscesses and DFIs resulted in an increased detection of all studied cSSSI pathogens: S. aureus, S. pyogenes, S. agalactiae, $S$. dysgalactiae, and $S$. anginosus group.

The current routine practice for the detection and identification of bacterial pathogens in cSSSI is culture of biopsy samples collected from the site of infection. Development of direct real-time PCR assays on bacterial DNA isolated from biopsy samples resulted in a higher detection of $34 \%$ for S. aureus, $37 \%$ for S. pyogenes, $18 \%$ for S. agalactiae, $4 \%$ for $S$. dysgalactiae subspecies equisimilis, and $7 \%$ for the $S$. anginosus group compared to standard cultures. No differences were observed for $S$. dysgalactiae subspecies dysgalactiae, which could be due to its low prevalence in human infections [17]. Significant differences were found between real-time PCR and culture assessment for $S$. aureus (major abscesses and DFIs), S. pyogenes (major abscesses and DFIs), S. agalactiae (major abscesses), $S$. dysgalactiae subspecies equisimilis (DFIs), and S. anginosus group (DFIs). Possible explanations for the real-time PCR-positive, culture-negative biopsy samples are: culture is less sensitive than real-time PCR for the detection of organisms, real-time PCR detects nonviable organisms in contrast to culture, splitting of the biopsy sample into two parts for culture and realtime PCR, contamination of the real-time PCR reagents, cross-reactivity of the real-time PCR assay with DNA from other organisms or human origin not controlled for during the development of the assay inducing false-positives.
In contrast, our real-time PCR assays did not identify some pathogens that were grown in culture. Possible explanations for the culture-positive, real-time PCR-negative biopsy samples are: real-time PCR is less sensitive than culture for the detection of organisms, incorrect determination during culture, low prevalence of bacterial DNA in the biopsy sample, splitting of the biopsy sample into two parts for culture and real-time PCR, low DNA yield or poor quality DNA after extraction or the presence of factors that inhibit the real-time PCR assay, poor target specificity, and/or competition between primers and probes within the developed real-time PCR not controlled for during the development of the assay.

Other studies evaluating the potential of direct real-time PCR in the detection of the organisms studied here frequently found comparable or increased detection rates compared to culture methods. The detection of (methicillin-resistant) $S$. aureus by real-time PCR was similar to culture in samples from skin and soft tissue infections and osteoarticular infections $[18,19]$, and increased in a screening for MRSA colonization [20]. In addition, the detection of S. pyogenes by realtime PCR was similar to culture in throat swabs from suspected pharyngitis [21, 22]. Furthermore, similar and increased detection rates of $S$. agalactiae were found in screening samples of vaginal and neonatal colonization [23-25], and increased detection was observed by real-time PCR for S. agalactiae in cerebrospinal fluid and blood from patients suspected of meningitis and sepsis [26].

Overall, combined detection by either culture and/or realtime PCR resulted in $85 \%$ of samples positive for $S$. aureus, $68 \%$ positive for $S$. pyogenes, $36 \%$ positive for $S$. agalactiae, $12 \%$ positive for $S$. dysgalactiae subspecies equisimilis, $0.7 \%$ positive for $S$. dysgalactiae subspecies dysgalactiae, and $20 \%$ positive for $S$. anginosus group. This again underlines the importance of Gram-positive cocci in cSSSIs. Interestingly, there are differences in the species present in major abscesses and DFIs. S. pyogenes was mainly detected in biopsies from major abscesses, whereas $S$. dysgalactiae subspecies equisimilis was mainly found in biopsies from diabetic foot infections. Other identified pathogens were similarly present in both major abscesses and DFIs. In addition, a clear distinction was observed between major abscesses and DFIs for PVL-positive $S$. aureus. $73 \%$ of the major abscesses, but only $14 \%$ of the DFIs, were positive for PVL. PVL is a bicomponent pore-forming toxin, encoded by the lukS-PV and lukF-PV genes, and is associated with lysis of leukocytes [27]. A recent meta-analysis confirmed the association between PVL and S. aureus skin and skin structure infections, which was not present for $S$. aureus invasive infections, such as pneumonia, musculoskeletal infections, and bacteremia [28].

In an attempt to evaluate the reliability of the real-time PCR and culture, we have calculated the sensitivity, specificity, PPV, and NPV. Both techniques were separately considered 
as the gold standard, as it is unknown which technique represents the "true" presence of pathogens in the biopsy samples.

In conclusion, current routine bacteriological assessment of biopsies by culture is time-consuming, requires viable pathogens, culture conditions suitable for growth, and results in lower detection sensitivity and may underestimate bacterial prevalence. However, given the fast and superior detection of cSSSI pathogens by real-time PCR, our study indicates that molecular analysis can be an additional method for the detection of bacteria in clinical samples.

Acknowledgments We are grateful to all the patients, investigators, and study centers who participated in the RELIEF clinical trial. Special thanks go to: Johanna Beekman (Bayer Healthcare, Berlin, Germany) for the collection, preparation, and storage of patient biopsy samples, and Corné Klaassen (Canisius-Wilhelmina Hospital, Nijmegen, the Netherlands) for his help with the laboratory methods of this study.

Funding This work was supported by an unrestricted grant from Bayer Healthcare. This study is part of the "Limburg Clinical Research Program (LCRP) UHasselt-ZOL-Jessa", supported by the foundation Limburg Sterk Merk, province of Limburg, Flemish government, Hasselt University, Ziekenhuis Oost-Limburg, and Jessa Hospital.

Conflict of interest MHT Stappers reports an unrestricted grant from Limburg Clinical Research Program (LCRP) UHasselt-ZOL-Jessa; IC Gyssens reports an unrestricted grant from Bayer Healthcare; $\mathrm{P}$ Reimnitz was an employee of Bayer Pharma AG during the conduct of the study; JW Mouton reports grants from Astra-Zeneca, Basilea, Merck, Cubist, Polyphor, Roche, Pfizer, and Jansen-Cilag; JF Meis reports grants from Astellas, Basilea, Merck, and MSD, and personal fees from Merck and Gilead; IC Gyssens reports grants from Pfizer outside the submitted work.

Open Access This article is distributed under the terms of the Creative Commons Attribution 4.0 International License (http:// creativecommons.org/licenses/by/4.0/), which permits unrestricted use, distribution, and reproduction in any medium, provided you give appropriate credit to the original author(s) and the source, provide a link to the Creative Commons license, and indicate if changes were made.

\section{References}

1. U.S. Food and Drug Administration (FDA) (1998) Guidance for industry. Uncomplicated and complicated skin and skin structure infections-developing antimicrobial drugs for treatment. Available online at: http://www.fda.gov/ohrms/dockets/98fr/ 2566dft.pdf. Accessed 12 September 2013

2. DiNubile MJ, Lipsky BA (2004) Complicated infections of skin and skin structures: when the infection is more than skin deep. J Antimicrob Chemother 53(Suppl 2):ii37-ii50

3. Lipsky BA, Weigelt JA, Gupta V, Killian A, Peng MM (2007) Skin, soft tissue, bone, and joint infections in hospitalized patients: epidemiology and microbiological, clinical, and economic outcomes. Infect Control Hosp Epidemiol 28(11):1290-1298

4. Stevens DL, Bisno AL, Chambers HF, Everett ED, Dellinger P, Goldstein EJ, Gorbach SL, Hirschmann JV, Kaplan EL, Montoya JG, Wade JC; Infectious Diseases Society of America (2005) Practice guidelines for the diagnosis and management of skin and soft-tissue infections. Clin Infect Dis 41(10):1373-1406
5. Gyssens IC, Dryden M, Kujath P, Nathwani D, Schaper N, Hampel B, Reimnitz P, Alder J, Arvis P (2011) A randomized trial of the efficacy and safety of sequential intravenous/oral moxifloxacin monotherapy versus intravenous piperacillin/tazobactam followed by oral amoxicillin/clavulanate for complicated skin and skin structure infections. J Antimicrob Chemother 66(11):2632-2642

6. Moet GJ, Jones RN, Biedenbach DJ, Stilwell MG, Fritsche TR (2007) Contemporary causes of skin and soft tissue infections in North America, Latin America, and Europe: report from the SENT RY Antimicrobial Surveillance Program (1998-2004). Diagn Microbiol Infect Dis 57(1):7-13

7. Mancini N, Carletti S, Ghidoli N, Cichero P, Burioni R, Clementi M (2010) The era of molecular and other non-culture-based methods in diagnosis of sepsis. Clin Microbiol Rev 23(1):235-251

8. Espy MJ, Uhl JR, Sloan LM, Buckwalter SP, Jones MF, Vetter EA, Yao JD, Wengenack NL, Rosenblatt JE, Cockerill FR 3rd, Smith TF (2006) Real-time PCR in clinical microbiology: applications for routine laboratory testing. Clin Microbiol Rev 19(1):165-256

9. Grif K, Heller I, Prodinger WM, Lechleitner K, Lass-Flörl C, Orth D (2012) Improvement of detection of bacterial pathogens in normally sterile body sites with a focus on orthopedic samples by use of a commercial $16 \mathrm{~S}$ rRNA broad-range PCR and sequence analysis. J Clin Microbiol 50(7):2250-2254

10. Sistek V, Boissinot M, Boudreau DK, Huletsky A, Picard FJ, Bergeron MG (2012) Development of a real-time PCR assay for the specific detection and identification of Streptococcus pseudopneumoniae using the recA gene. Clin Microbiol Infect 18(11):1089-1096

11. Zbinden A, Köhler N, Bloemberg GV (2011) recA-based PCR assay for accurate differentiation of Streptococcus pneumoniae from other viridans streptococci. J Clin Microbiol 49(2):523-527

12. Tamura K, Stecher G, Peterson D, Filipski A, Kumar S (2013) MEGA6: Molecular Evolutionary Genetics Analysis version 6.0. Mol Biol Evol 30(12):2725-2729

13. Hopman J, Peraza GT, Espinosa F, Klaassen CH, Velázquez DM, Meis JF, Voss A (2012) USA300 Methicillin-resistant Staphylococcus aureus in Cuba. Antimicrob Resist Infect Control $1(1): 2$

14. Glazunova OO, Raoult D, Roux V (2010) Partial recN gene sequencing: a new tool for identification and phylogeny within the genus Streptococcus. Int J Syst Evol Microbiol 60(Pt 9):2140-2148

15. Gao XY, Zhi XY, Li HW, Klenk HP, Li WJ (2014) Comparative genomics of the bacterial genus Streptococcus illuminates evolutionary implications of species groups. PLoS One 9(6):e101229

16. Olson AB, Kent H, Sibley CD, Grinwis ME, Mabon P, Ouellette C, Tyson S, Graham M, Tyler SD, Van Domselaar G, Surette MG, Corbett CR (2013) Phylogenetic relationship and virulence inference of Streptococcus anginosus group: curated annotation and whole-genome comparative analysis support distinct species designation. BMC Genomics 14:895

17. Vandamme P, Pot B, Falsen E, Kersters K, Devriese LA (1996) Taxonomic study of Lancefield streptococcal groups C, G, and L (Streptococcus dysgalactiae) and proposal of S. dysgalactiae subsp. equisimilis subsp. nov. Int J Syst Bacteriol 46(3):774-781

18. Wolk DM, Struelens MJ, Pancholi P, Davis T, Della-Latta P, Fuller D, Picton E, Dickenson R, Denis O, Johnson D, Chapin K (2009) Rapid detection of Staphylococcus aureus and methicillin-resistant S. aureus (MRSA) in wound specimens and blood cultures: multicenter preclinical evaluation of the Cepheid Xpert MRSA/SA skin and soft tissue and blood culture assays. J Clin Microbiol 47(3): $823-826$

19. Dubouix-Bourandy A, de Ladoucette A, Pietri V, Mehdi N, Benzaquen D, Guinand R, Gandois JM (2011) Direct detection of Staphylococcus osteoarticular infections by use of Xpert MRSA/SA SSTI real-time PCR. J Clin Microbiol 49(12):42254230 
20. Herdman MT, Wyncoll D, Halligan E, Cliff PR, French G, Edgeworth JD (2009) Clinical application of real-time PCR to screening critically ill and emergency-care surgical patients for methicillin-resistant Staphylococcus aureus: a quantitative analytical study. J Clin Microbiol 47(12):4102-4108

21. Dunne EM, Marshall JL, Baker CA, Manning J, Gonis G, Danchin MH, Smeesters PR, Satzke C, Steer AC (2013) Detection of group A streptococcal pharyngitis by quantitative PCR. BMC Infect Dis $13: 312$

22. Dawson ED, Taylor AW, Smagala JA, Rowlen KL (2009) Molecular detection of Streptococcus pyogenes and Streptococcus dysgalactiae subsp. equisimilis. Mol Biotechnol 42(1):117-127

23. Bergeron MG, Ke D, Ménard C, Picard FJ, Gagnon M, Bernier M, Ouellette M, Roy PH, Marcoux S, Fraser WD (2000) Rapid detection of group B streptococci in pregnant women at delivery. N Engl J Med 343(3): 175-179

24. Gavino M, Wang E (2007) A comparison of a new rapid real-time polymerase chain reaction system to traditional culture in determining group B Streptococcus colonization. Am J Obstet Gynecol 197(4):388.e1-388.e4

25. Natarajan G, Johnson YR, Zhang F, Chen KM, Worsham MJ (2006) Real-time polymerase chain reaction for the rapid detection of group B streptococcal colonization in neonates. Pediatrics 118(1):14-22

26. de Zoysa A, Edwards K, Gharbia S, Underwood A, Charlett A, Efstratiou A (2012) Non-culture detection of Streptococcus agalactiae (Lancefield group B Streptococcus) in clinical samples by real-time PCR. J Med Microbiol 61(Pt 8):1086-1090

27. Kaneko J, Kamio Y (2004) Bacterial two-component and heteroheptameric pore-forming cytolytic toxins: structures, pore-forming mechanism, and organization of the genes. Biosci Biotechnol Biochem 68(5):981-1003

28. Shallcross LJ, Fragaszy E, Johnson AM, Hayward AC (2013) The role of the Panton-Valentine leucocidin toxin in staphylococcal disease: a systematic review and meta-analysis. Lancet Infect Dis 13(1):43-54 